\title{
Bridging entrepreneurial competencies and business model innovation: insights on business renewal in the small horticulture businesses in Finland
}

\author{
Taina Eriksson ${ }^{1}$, Hilkka Halla², Marikka Heikkilä ${ }^{1}$ and Helka Kalliomäki ${ }^{1}$ \\ ${ }^{1}$ University of Turku, Fl-20014 Turun yliopisto, Finland \\ ${ }^{2}$ Yrityssalo Ltd., Joensuunkatu 7, Fl-24100 Salo, Finland \\ e-mail: taina.eriksson@utu.fi
}

\begin{abstract}
Entrepreneurial competencies are connected to venture performance, but the link between these competencies and the business model (BM) innovation is scarcely studied. This article is among the first to study entrepreneurial competencies as a driving force for BM innovation. This paper presents a qualitative empirical study of six innovative horticulture entrepreneurs in Finland. We contribute to two separate literature streams, competence and BM literature, by combining competence categories (Mitchelmore and Rowley 2010) and BM Innovation model (Foss and Saebi 2017) in the analysis of innovative entrepreneurs. This paper provides evidence on entrepreneurial competencies being internal drivers for BM innovation, and also identifies the core entrepreneurial competences related to BM innovation.
\end{abstract}

Key words: business renewal, competency framework, entrepreneurship, qualitative research

\section{Introduction}

The operating environment of the producers in the Finnish horticulture industry has changed a lot since the 1990's. The national borders have opened for imports and many sectors within the industry are struggling with profitability (Rikkonen and Aakkula 2012). The ability to do business has become much more pronounced (ibid) and there is a need for transformation to maintain the industry. Similar to other industries, versatile new initiatives appear to be arising among start-ups and other small companies.

To survive in the open and more competitive market, the primary producers need to operate as business owners and entrepreneurs. Great majority of the companies are micro enterprises that employ fewer than 10 people, and the entrepreneur is a critical factor influencing the firm success (Kyndt and Baert 2015). A notable share of the horticulture business owners still appear to be purely production oriented (Silvertsson and Tell 2015) Their abilities to develop their business models (BM) varies according to factors related e.g. to education and ability to recognize and seize opportunities.

The Finnish situation is not unique. Also in other countries the producers in the horticulture operate as business owners. For instance, Mulder et al. (2007) and Lans et al. (2010) studies testify the growing importance of entrepreneurship: "where the focus in agriculture in the past was predominantly on the technical/craftsman role, the managerial and entrepreneurial role has gained importance" (Mulder et al. 2007).

Entrepreneurial competencies have been recognized to have a connection to the venture performance (Chandler and Jansen 1992, Pukkinen 2018). Yet, the competencies that are overall linked to entrepreneurship are scarcely studied (Kyndt and Baert 2015). Specifically, the literature is silent on the linkages between entrepreneurial competencies and the ability to renew the business and develop new business models (BMs) (Santandreu-Mascarell et al. 2013, Heikkilä and Heikkilä 2017, Lampela et al. 2017, Pukkinen 2018). Along the same lines, Foss \& Saebi (2017) argue that there is a gap in our understanding of the internal drivers of BM innovation.

In this paper, we examine the characteristics and competencies of industry renewing entrepreneurs and identify factors that are linked to the entrepreneurs' propensity to innovate their BMs and take initiative to create change in the industry. The study addresses the following research question: What kind of entrepreneurial competences drive business model innovation? 
The research question is addressed through qualitative empirical study of six small horticulture entrepreneurs. The study compares and contrasts two different types of entrepreneurs. One group are running established family businesses on farms they have inherited. The other group have set up new business and hence there is no heritage related to the firm.

The study develops an entrepreneurial BM innovation competency framework that helps to understand and explain the influence of internal drivers on BM innovation. The framework brings together the stands of literature focusing on entrepreneurial competencies and BM innovation. In the context of horticulture industry, new knowledge is produced to profile the entrepreneurs capable of contributing to horticulture industry renewal. This has implications, for instance, on vocational and higher education. Furthermore, research contributions are related to entrepreneurial competency literature through the identification of entrepreneurial competency profiles. Extant literature has focused on generic entrepreneurial competency, and not on variations between individual entrepreneurs. In addition, BM innovation literature is developed by presenting new empirical evidence on entrepreneurial competencies as drivers for BM innovation.

The rest of the paper is structured as follows. First, we outline theoretical definitions and views on BM innovation and entrepreneurial competencies, and propose an entrepreneurial BM Innovation competency framework. Thereafter we describe the empirical research methods and data that are followed by findings, analysis and discussion. Conclusions are the final section of the article.

\section{Theoretical views on entrepreneurial competencies and business model innovation}

A firm's resources render services that are inputs into the productive processes. The same resources can be used for different purposes and in different combinations. Most importantly, firms' ability to extract services from resources differs (Penrose 1959). In the case of small and micro firms, the role of the entrepreneur in this is critical (Man et al. 2008). Therefore, this study focuses on the entrepreneur. Before looking into the competencies, we first discuss BM innovation.

\section{BM innovation}

For the last two decades researchers in various disciplines, such as strategic management, innovation management and information systems, have included BM as one of the main objects of study (DaSilva and Turkman 2014). Recently researchers have begun reaching a consensus on its definition: BM refers to the logic of creating, capturing and delivering value for customers and business (Wirtz et al. 2016). Typically, it consists of the value proposition, customer segment, financials, key activities and resources, and partners. It is considered as a new unit of analysis that is distinct from the product or firm and that can be a subject of innovation (Zott et al. 2011).

BM Innovation is typically not a straightforward task. Instead, Berends et al. (2016) shows how BM innovation is a complex multi-step process where organizational action and cognition intertwine. It is described as an activity or process in which core elements of a firm and its business logic are deliberately altered (Pohle and Chapman 2006, Lindgardt et al. 2009, Bucherer et al. 2012, Hartmann et al. 2013, Bonakdar 2015, Heikkilä et al. 2018). A review of the BM innovation research from the past 15 years (Foss and Saebi 2017) reveals that the process of BM innovation is still not well understood, especially with respect to its antecedents, contingencies, and outcomes.

The practical importance of BM innovation has been underlined, for instance by the EU, which has identified it as a major source for competitive advantage, economic growth and job creation, particularly in micro, small and medium sized enterprises (SMEs) (EASME 2015). Even though small companies have fewer resources, there is growing evidence that entrepreneurial passion and originality can compensate limited resources (Stenholm and Renko 2016) and has a strong influence in the initial stages of the BM innovation (Heikkilä and Heikkilä 2017).

An example of BM innovation within agri-business is when the entrepreneur utilises the firm's unique resources in new ways to create business. These resources can be material or immaterial, such as buildings or land hired out for lodging, fishing and hunting, or education or work experience giving possibility for pedagogic services or courses (Vik and McElwee 2011). The new business idea is not necessarily embedded in farming activities. For instance, a hobby combined with the farm premises provides a combination of resources that is valuable and unique, and which cannot easily be imitated by competitors (Alsos et al. 2003). 
In agriculture, main hindrances to BM innovation are often human related, such as individuals' attitudes and traditions (Sivertsson and Tell 2015). For example, Lampela et al. (2017) investigating the relationship between entrepreneurial competencies and BM innovation in SMEs in the metal and forest industries identified positive attitude to change as well as activeness in external networking and in seeking new opportunities as key skills for BM innovation. A case study of BM innovation in agricultural biogas production adds business strategy to the list above (Karlsson et al. 2017). It should be remembered that many agricultural businesses are family owned. Literature typically considers family businesses as traditional and risk-averse (Duran et al. 2016). Resent research, however, claims that family firms' attitude towards risk and innovation is more nuanced: they do not grasp business opportunities that may reduce their socioemotional wealth, but on the other hand, if the firm's socioemotional wealth is threatened they are willing to seek riskier innovations in order to protect it (Meroño-Cerdán et al. 2018).

An important distinguishing factor is the type of change: is it a gradual improvement of an existing BM or design of a new BM (Schneider and Spieth 2013). Incremental innovation refers to cases in which the BM is changed only little, or in small steps during a longer time period. Radical innovation means that the BM is changed in many aspects, and is thus new to the firm, and even to the markets it is operating in (Bucherer et al. 2012, Cortimiglia et al. 2016). An example of radical change in agriculture is when a farm changes its business from cultivation of crop to harvesting of solar energy (Huijben and Verbong 2013).

BM literature points out the importance of drivers for the innovation: the driver may be external or internal (Demil and Lecocq 2010). In the context of farming, the entrepreneur could, for instance be forced to BM innovation when the continuity of the farm is threatened because of external forces such as fierce competition or development of farming technology (Alsos et al. 2003). Examples of internal drivers are, in turn, entrepreneur's strategic decisions and the natural development of interactions between BM components leading to BM innovation. However, as Foss and Saebi (2017) found out, there are still significant gaps in the understanding of the internal drivers of BMI. They strongly suggested further research to look into (dynamic) capabilities literature for new insight on internal drivers of BM innovation. Therefore, in this paper we investigated what kind of entrepreneurial competences drive business model innovation in small agricultural companies.

\section{Entrepreneurial competency}

An entrepreneur is a person who, rather than working as an employee, sets up a business or businesses, taking on financial risks in the hope of profit (English Oxford Dictionary). The concept of entrepreneurship is often associated with the behavioral or attitudinal characteristics of entrepreneurs (Ucbasaran et al. 2001); for instance, Wagener et al. (2010) describe entrepreneurs possessing high level of independence, tolerance of ambiguity, risk-taking propensity, innovativeness and leadership qualities (Wagener et al. 2010). Despite existing in many forms, entrepreneurship is mostly connected with small firms (Stevenson and Jarillo 1991).

An entrepreneur sustains temporal tension, strategic focus and intentional posture (Bird 1995). Temporal tension means that the entrepreneur actively links the present with the future and is conscious about the importance of timing. Strategic focus refers to the goal and methods of conducting business (ibid). Earlier research has found that successful farmers have strong emphasis on instrumental goals (Mäkinen 2013). Entrepreneurs who have clear business goals can be expected to perform better financially than the ones who prioritize "life style oriented" goals. Finally, intentional posture implies that the entrepreneur's internal values, beliefs and needs are aligned and consistent with the outer world and the level of role conflict is low. (Bird 1988, Bird 1995) In addition, an entrepreneur is able to form emotionally positive, yet instrumental relationships within the firm and externally. Family businesses form a special subset, where the entrepreneur manages the overlapping business and family systems and cultures (Bird 1995).

In the context of farming it has been noted that the business owner is primarily interested in profitability, because it is seen to control the viability of the business (Mäkinen 2013). Nonetheless, Mattila et al. 2008 found that in the case of investment decisions, other than economic reasons weighed the most. The most profound reasons for decisions made about large investment deal with achieving better life and working conditions in a sustainable way. In addition, farmers told that they measure the success of investment primarily in qualitative and non-economic terms (Mattila et al. 2008).

In research concerning the entrepreneur's role in the success of small firms, there can be identified two distinct streams of literature: the competency-based examination and the personality-based examination (Wagener et al. 2010). 
In this study, we focus on the competencies. A competency can be approached as a minimum standard, a threshold that must be achieved or as behavior that individual demonstrates and that contributes to success (Bird 1995, Mitchelmore and Rowley 2010). In this study we take the latter approach and examine competencies for creating BM innovation.

On the organizational level competency is "repeatable, learning-based and therefore non-random ability to sustain the coordinated deployment of assets and resources enabling the firm to reach and defend the state of competitiveness and to achieve the goals" (Freiling 2004). Even though this study focuses on competency of an individual, this definition carries important features. First of all, repeatability and being non-random are critical characteristics of competencies. This means that they can offer reliable basis for operations. Second, it is also important to note that competency is based on learning and therefore they can be developed. Competencies are generally changeable (Bird 1995) and they can be learned or attained through education or experience (Kyndt and Baert 2015). Furthermore, the entrepreneur's competencies are argued to result in decisions regarding the firm operations (Bird 1995). Even more importantly, competency must be demonstrated in a person's actions or behavior (Man et al. 2008), only then they can have an impact on the firm.

Entrepreneurial competencies are typically linked to the development of small or new firms, as opposed to managerial competencies which relate to growing and maintaining the business (Mitchelmore and Rowley 2010). Entrepreneurial competencies have been studied from different perspectives. First, and foremost there is the connection between entrepreneurial competency and the venture performance (Man et al. 2008, Koryak et al. 2015). Entrepreneurial competencies are also examined from the perspective of training and how the competencies can be developed for instance in universities (Gümüsay and Bohné 2018). On the other hand, the competency development is also examined in relation to the propensity to start a business (Sánchez 2011). Yet, the picture is incomplete and more research is needed. Entrepreneurial competencies are difficult to measure, because the essences of the competency is in how people behave (Mitchelmore and Rowley 2010, Mitchelmore and Rowley 2013). Therefore, the framework of these competencies must be further developed to enable in-depth investigation and better understanding of entrepreneurship process. More solid frameworks would also enable more reliable measurements of entrepreneurial competencies that are necessary for instance in defining the influence of different learning initiatives on competency development.

Mitchelmore and Rowley (2010), and also e.g. Loué \& Baronet (2012), Santandreu-Mascarell et al. (2013) have reviewed the research on entrepreneurs' key competencies and come up with four domains (Fig. 1): entrepreneurial competencies, business and management competencies, human relations competencies and conceptual and relationship competencies (see Appendix 1 for more detailed description of the framework). As previously discussed, entrepreneurial competencies are often seen necessary in creating and renewing business, whereas business and management competencies are more important in maintaining the business. Therefore, in this study we focus on the entrepreneurial competencies and lean on the categorization by Mitchelmore and Rowley. It provides a useful distinction between entrepreneurial and managerial competencies as well as human relations and conceptual and relationship competencies that are related to running a viable business more generally.

According to the framework, entrepreneurial competencies include skills for identification and definition of a viable market niche; development of products or services appropriate to the chosen market niche/product innovation; idea generation; environmental scanning; recognizing and envisioning taking advantage of opportunities, and formulating strategies for taking advantage of opportunities (Mitchelmore and Rowley 2010). These competencies also relate to the potential BM innovation the entrepreneur engages in.

\section{An entrepreneurial BM innovation competency framework}

In this article we develop an entrepreneurial BM innovation competency framework to connect the separate literatures on BM and entrepreneurial competencies to better understand the role of competencies in horticulture industry's renewal through BM innovation. To contribute to industry renewal, entrepreneurs have to have certain competencies to develop and innovate their BMs, but the link between competencies and the BM innovation has not been thoroughly studied (Heikkilä and Heikkilä 2017, Lampela et al. 2017, Pukkinen 2018). Yet, the link between the two is often supposed; as Mitchelmore and Rowley (2010 referring to Baum 1994, Bird 1995) state, "interest in entrepreneurial competence derives from the supposed link between competencies and the birth, survival and growth of a venture". 


\begin{tabular}{|c|c|}
\hline $\begin{array}{l}\text { Entrepreneurial competencies } \\
\text { - Identification of a viable market niche } \\
\text { - Development of products of services/ } \\
\text { product innovation } \\
\text { - Idea generation } \\
\text { - Environmental scanning } \\
\text { - Recognising and envisioning taking } \\
\text { advantage of opportunities } \\
\text { - Formulating strategies for taking advantage } \\
\text { of opportunities }\end{array}$ & $\begin{array}{l}\text { Business and management competencies } \\
\text { - Development of the management system } \\
\text {-Acquisition and development of resources } \\
\text { - Business operational skills } \\
\text { - Previous involvement with start-ups } \\
\text {-Managerial experience } \\
\text { - Familiarity with industry } \\
\text { - Financial and budgeting skills } \\
\text {-Previous experience } \\
\text {-Management style } \\
\text {-Marketing skills } \\
\text {-Technical skills } \\
\text {-Industry skills } \\
\text {-The ability to implement strategy } \\
\text { - Familiarity with the market } \\
\text { - Business plan preparation } \\
\text { - Goal setting skills } \\
\text {-Management skills }\end{array}$ \\
\hline $\begin{array}{r}\text { KEY CON } \\
\text { ENTR }\end{array}$ & $\begin{array}{l}\text { ENCIES OF } \\
\text { NEURS }\end{array}$ \\
\hline $\begin{array}{l}\text { Acquisition and development of } \\
\text { resources } \\
\text { - Development of the organizational culture } \\
\text { management feel is necessary to guide the } \\
\text { firm } \\
\text { - Delegation skills } \\
\text { - The ability to motivate others individual and } \\
\text { in groups } \\
\text { - Hiring skills } \\
\text { - Human relations skills } \\
\text { - Leadership skills }\end{array}$ & $\begin{array}{l}\text { Human relations competencies } \\
\text {-Development of the organizational culture } \\
\text { management feel is necessary to guide the } \\
\text { firm } \\
\text {-Delegation skills } \\
\text { - The ability to motivate others individual and } \\
\text { in groups } \\
\text { - Hiring skills } \\
\text { - Human relations skills } \\
\text { - Leadership skills }\end{array}$ \\
\hline
\end{tabular}

Fig. 1. A summary of key competencies (Mitchelmore and Rowley 2010)

As entrepreneurial competencies are found to be a distinct set of competencies that are highly relevant to entrepreneurship (Mitchelmore and Rowley 2010), we develop the entrepreneurial BM innovation competency framework for the purposes of our empirical analysis in the context of horticulture industry renewal by focusing especially on the entrepreneurial competencies identified in Mitchelmore and Rowley's framework (Fig. 2).

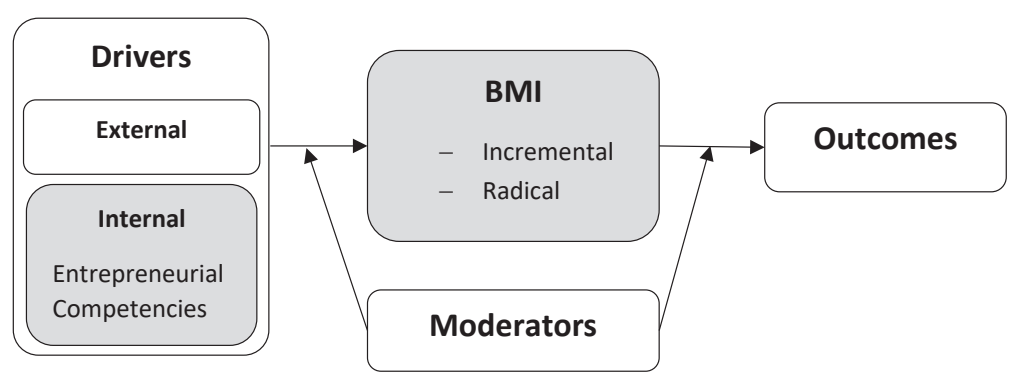

Fig. 2. Entrepreneurial BM innovation competency framework (Modified from Foss \& Saebi 2017)

In the framework the focus is on the competencies of entrepreneurs to generate and scan ideas as well as to build on those ideas and opportunities, which are critical for BM and industrial renewal and will result in BM innovation. Based on earlier research we can distinguish between the external and the internal drivers of BM innovation (Demil and Lecocq 2010). This examination focuses on the entrepreneurial competencies (adapted from Mitchelmore and Rowley 2010) as internal drivers of BM innovation. 
The BM innovation, is evaluated on its innovativeness by categorizing it either as radical "BM that bring discontinuity to market/industry" or incremental innovation" different BM, but no substantial discontinuity" (Cortimiglia et al. 2016). Even though both innovativeness types may, in the long run, contribute to the viability, certainly the first will more likely have higher potential to renew or disrupt the industry.

\section{Research approach and methodology}

This research was done following the critical realist perspective (cf. Fleetwood 2005) and a data-driven approach that can be categorized as abductive; it was an iterative process between empirical data and theory (cf. Dubois \& Gadde 2002). The approach was selected due to scarce understanding and relatively scattered literature on the topic.

The research process initiated with qualitative interviews that focused on BM innovation by the entrepreneurs. The interviewees were allowed to tell rather freely about the issues they see as important in relation to BM innovation. The interviewer utilized a list of supporting questions based on earlier literature to make sure all elements of BM are covered (cf. Zott et al. 2011). The interviewees were informed of the focal themes of the interviews in advance. To avoid social desirability bias, we let the interviewees tell about the issues they perceive important (Fisher 1993, Lans et al. 2010).

The entrepreneurs to be interviewed were identified based on the researchers' knowledge of the industry, following the media and discussions with industry experts. The key selection criterion was that the entrepreneur has engaged in BM innovation in the horticulture industry recently. The goal was to reach information-rich cases from the perspective of this study (cf. Patton 2002). The empirical material consists of 13 interviews with entrepreneurs conducted in 2015-2016. Most entrepreneurs were interviewed twice; one of them three times. Average duration of an interview was 59 minutes.

Three of the case companies are family farms that had relatively recently undergone the transfer to the next generation; Alpha's and Beta's main products are vegetables, Gamma produces also berries. Delta and Epsilon were established less than ten years prior to the interviews; Delta is producing green walls and Epsilon special salads The sixth entrepreneur runs a greenhouse company, established in the early 2000 s and produces salads and herbs. Key facts of the companies are presented in Table 1 below.

Table 1. Company and entrepreneur facts

\begin{tabular}{lcccc}
\hline Company & $\begin{array}{c}\text { Established } \\
\text { (year) }\end{array}$ & $\begin{array}{c}\text { Employees (high season/ } \\
\text { off-season) }\end{array}$ & $\begin{array}{c}\text { Turnover } \\
1000 €\end{array}$ & $\begin{array}{c}\text { Entrepreneur's education } \\
\text { Non family }\end{array}$ \\
\hline Alpha & 1751 & $5 / 2$ & 700 & $\begin{array}{c}\text { Natural Resources Polytechnic } \\
\text { degree }\end{array}$ \\
$\begin{array}{l}\text { Beta } \\
\text { Gamma }\end{array}$ & $1970 \mathrm{~s}$ & $30 / 3$ & 750 & Horticulture Polytechnic degree \\
Delta & 1944 & $120 / 5$ & 700 & Natural Resources Polytechnic \\
degree & Family \\
Epsilon & 2011 & $48 / 48$ & 1794 & Science and economics, Academic- \\
Zeeta & 2012 & $4.5 / 4$ & 519 & Non family \\
\hline
\end{tabular}

After the first round of interviews, we approached the empirical data with an open mind and a literature-based understanding of the significance of the entrepreneur to BM innovation in small firms. The goal was to identify dimensions that the entrepreneur raised in relation to BM innovation. The initial read was data-driven. One member of the research team identified themes that recur in the entrepreneurs' accounts of the BM innovation. After initial analyses particularly the entrepreneurial competencies were recognized as a focal factor. The theoretical frame was sharpened based on this notion to steer additional data collection and more detailed analysis of the drivers of BM innovation. 
A second round of interviews was conducted after the initial analyses. It focused more deeply on the issues that were identified focal in the initial analyses. Particularly we tackled the entrepreneurs' competencies. In the actual analyses after completing the data collection, we first examined whether the BM innovations by the entrepreneurs can be characterized as incremental or radical. Thereafter the entrepreneurial competencies of each entrepreneur were scrutinized against the theoretical frame. As explained earlier, Mitchelmore and Rowley (2010) framework was found the most suitable.

The analysis benefited from investigator triangulation and involved a lot of discussion amongst the research team. The initial read and theme searching (cf. Gioia et al. 2013) was done by a team member who was not involved in the interviews. Another member of the research team coded the interview transcripts according to the themes of the framework. The coding procedure was carefully initiated in collaboration between two researchers to develop a shared understanding of how to decide which excerpts to code under which theme. After having coded the interviews, the sections coded under each code were discussed among the research team to make sure the team agrees on the coding.

Next, we formed individual Competency profiles for each case. The research team evaluated the level of each entrepreneur's competencies 1 ) in relation to the other examined entrepreneurs' competencies and 2) in relation to the entrepreneur's other competencies (analyzing which competencies appear to be the strongest/weakest for each entrepreneur). At the last stage of analysis, the quotes coded for entrepreneurial competencies were scrutinized against the Competency profiles and reflected against the overall research framework.

\section{Findings}

Even though, their processes varied a lot, trial-and-error type of a learning was the common characteristics of the processes leading to their new BMs. In some cases, the BM innovation has focused more on adding value through innovative production technologies and scalable solutions, whereas in other cases the focus has been on customer insight and deep understanding of the market. Next, we will look into the interviewees' entrepreneurial competencies as an internal driver of BM innovation. Thereafter, we analyze the radicalness of the BM innovation by the entrepreneurs.

\section{Entrepreneurial competencies}

Internal drivers were clearly emphasized in the interviewed entrepreneurs' motivations to engage in BM innovation. Four out of the six entrepreneurs emphasized very strongly the internal drivers and particularly issues related to their own competencies. For instance Epsilon entrepreneur told about his motivations behind BM innovation: "I managed to make it work in Excel. In practice cash flow calculations roughly functioned. Nothing more romantic than that." External drivers had a notable role in the BM innovation by two of the entrepreneurs. However, also in their case the internal drivers were clearly identifiable.

All in all, the entrepreneurs talked a lot about issues that are linked to their competencies and therefore, the way entrepreneurial competencies are manifested in the entrepreneurs' operations are analyzed in the following. Based on the findings, we construct entrepreneurial competency profiles (see Appendix 1) where the entrepreneurial competencies of the examined entrepreneurs are compared against the other entrepreneurs of the study. Hence, the competence profile must be interpreted as an indicative evaluation of which issues the entrepreneurs emphasize in their operations.

Identification of market - In terms of identifying the market, the entrepreneur's competence to develop customer understanding stands out in the entrepreneurs' talk and actions. All six entrepreneurs emphasize the importance of customer insight. Regardless of the sales channel, the entrepreneurs want to understand the end user. Knowledge of the end user gives better possibilities to foresee changes or opportunities that originate in the market. The capacity and urge to understand the customer and the end user is an important feature of the examined entrepreneurs. Alpha entrepreneur bases strategic decisions (e.g. what to produce) on the knowledge of the consumer demand and its expected developments. In addition, Gamma entrepreneur stated: "The customer comes very close... When the retailer-producer [relationship] is functioning well we know all the feedback". In addition, the entrepreneurs emphasized that social media makes consumer feedback visible. Instead of only listening to the feedback on haphazard basis, the entrepreneur now gets feedback more systematically. 
The identification of the target market varies from Epsilon targeting basically everyone who eats to an iterative process of Delta where the target market, and particularly the segments were identified by reflecting accumulated experiences against the entrepreneurial vision. This led to emphasizing the positive effects instead of trying to solve customers' problems. Each entrepreneur has done a lot of work in deciding which market is the one where they want to operate.

Product innovation - Horticulture industry is not particularly known for its innovative products. Nonetheless, the interviewed entrepreneurs all had some linkages to innovations (product, service or production process). Company Delta has the most innovative product that is a novel application of a biological process and use of technology. In the other firms, innovation is apparent particularly in their production processes, but also in services or marketing for instance. In company Beta, innovation is the most evident in the machines tailored for their own production to enhance competitiveness of the products. Also, product selections of Gamma, Epsilon and Zeeta have innovative elements in them, mostly related to production processes and utilization of technology. In Alpha, the entrepreneur made a notable innovation by expanding from traditional products to service operations. The services are built on the utilization of existing resources, but they require business model that is different from the original product-based business model. Hence, the service innovation has called for a novel parallel BM.

Idea generation - The examined entrepreneurs manifest their inclination towards idea generation in different ways. Delta, Epsilon and Zeeta businesses have originated from the entrepreneurs' ideas, which is the primary indication of their idea generation abilities. The entrepreneurs in Alpha, Beta and Gamma have all become predisposed to the entrepreneurial idea generation by their parents, and they are continuing the legacy. In Gamma, the entrepreneur has put in place a production control system and a cash register system combined with an online store that all yield a lot of new information to support the operations. The comprehensiveness of the approach is novel in the sector and enables basing all decisions on data.

The entrepreneurs have been able to generate ideas in terms of most elements of the business model, particularly the cost structure, revenue streams, the customer relationship, the key resources and activities. The vision of the entrepreneur seems to be the driving force for idea generation. The Epsilon entrepreneur describes the firm as " a limited company based tool for me to try out the functionality of my ideas in the real world." All in all, the actions of every examined entrepreneur demonstrate idea generation competency.

Environmental scanning - Environmental scanning plays an important role in all of the six examined companies. The interviewed entrepreneurs told about constantly being alert to signals that may be relevant to their business. For instance, Delta entrepreneur told about the adjustments in marketing and sales tactics they have made based on their observations of the environment.

All of the entrepreneurs talk about their customers as well as the end users. Alpha entrepreneur told about keeping track of trends among consumers: "product safety, remnants of pesticides. Maybe such that the consumers will be more aware of and want to buy safe foods." The emphasis is on the consumer as Gamma entrepreneur put it: "I follow a lot of consumer reactions to different things. Public administration defines the frame for the operations. But consumers are the ones to define the emphases: what kind of products they search for, what they are interested in, so we have to modify our operations and communications." Furthermore, the entrepreneurs told that they keep track of trends in the market; what are the current and potential competitors doing. Particularly for Alpha, Beta and Gamma, active discussions with other producers in the same sector play an important role in the scanning.

On the other hand, the entrepreneurs' operations show that they also scan for technological developments. Epsilon entrepreneur explained the role of technology in the growth of the firm: "there won't be more than ten employees. Then I have to outsource so that robots do the job. Clearly robotization and digitization has changed the playing field significantly and many more changes will follow." Also, Zeeta entrepreneur told about the importance of utilizing new technology: "to maximize the yield per square meter. Here again the lighting technology, cooling and humidity removal technologies play a significant role." On the other hand, small companies cannot afford to make trials with dysfunctional or unsuitable technologies and therefore, good partners are emphasized with most of the interviewed entrepreneurs.

Recognizing opportunities - The capability of recognizing opportunities is closely linked to environmental scanning and it seems to be at the core of the interviewed entrepreneurs' capabilities. Everyone's business model is built on recognized opportunities. For instance, Epsilon entrepreneur became entrepreneur through an extensive and systematic search for a business to start or to buy. Also Zeeta entrepreneur has demonstrated strong capability in 
opportunity recognition by partnering with a global technology corporation to develop new to the world concept. Importantly, the entrepreneurs appear capable of making use of the identified opportunities. Alpha entrepreneur had identified the opportunity of deriving benefits from pesticide-free cultivation. In addition to the all-important fact-based image of purity of the produce, there are also quality benefits that lead to economic gains. Also Zeeta entrepreneur testifies to the competency to making use of the opportunities. He has been able to leverage the knowledge from prior operations into a novel type of greenhouse production. This has called for collaboration with various partners, but also a lot of knowledge-based confidence from the entrepreneur. Gamma entrepreneur has been able to leverage networks to recognize opportunities and make business out of them.

Formulating strategies - competency in formulating strategies can be seen in how the entrepreneurs have striven towards their business goals. Delta, Epsilon and Zeeta entrepreneurs all have had a strong strategic vision to make the business internationally scalable. This has guided the entrepreneurs' decisions and the BM innovation. As expressed by Delta entrepreneur: "in a way we are a bit in a hurry to get out of Finland, or this is not the target country where we want to... or it is difficult to operate." Delta has already international operations, but for Epsilon and Zeeta, internationalization remains a target that they strive for. Interestingly, Zeeta entrepreneur perceives that the lack of conventional training to the field has enabled him to "ask questions that may be stupid and do stupid things". This has led to novel approach to cultivation.

For the Epsilon entrepreneur strategic vision includes also motivating business partners to develop. The idea is that you can expect your partners to respond to your call for development when you engage in development yourself. The importance of partners for realizing the strategies was emphasized also by the other entrepreneurs.

Alpha, Beta and Gamma entrepreneurs have taken on running the family farm and hence their starting point has been very different. Nonetheless, also each one of these entrepreneurs have adopted a strategic perspective to running the company. They have had to acknowledge the choices made by their parents. Instead of new strategies, they have sought for a balance between proven practices and renewal. "We want to be the seller and producer of domestic berries. -- The goal is to increase the share of processed products in our offering little by little." These kind of strategic goals stem from understanding the market and opportunities and they steer BM innovation. The strategic perspective of the entrepreneurs is visible basically in all of the above discussed entrepreneurial competencies. Particularly the identification of the market, environmental scanning as well as recognizing and making use of opportunities are all tightly linked to formulating strategies by the entrepreneurs.

\section{Innovativeness of the BM}

The innovativeness of the BMs is evaluated in relation to the firm and the market more broadly. The BM innovations of Alpha, Beta and Gamma were considered as incremental: they represent novel elements to the firm, but not to the market. The BM innovations by Delta, Epsilon and Zeeta were considered radical since they include also novelty to the market.

Alpha entrepreneur has developed the BM during recent years, but the family legacy is clearly present in the change. The entrepreneur emphasizes the security of supplies and product quality. Most recently, the operations have been expanded through a new limited company where the responsibility is shared with a business partner from outside the family to manage risks. Moreover, Alpha entrepreneur has been able to leverage external threats by incremental changes to its BM. Services that are not directly linked to the core products have been added to the offering to make use of the existing resources (e.g. storage services for boat-owners).

Beta entrepreneur has incrementally changed the BM towards being more specialized in core farming products. Beta has made several small adjustments to their BM, mainly by focusing on niché products: "small plants, small in the sense of total cultivation area in Finland. The advantage for us is that there is less competition and thus demand for low cost production is not so high". The goal is to come closer to the consumer, and towards that end marketing channels were renewed. The goal is to produce what the consumers are willing to pay for. The new BM includes also new capital investment in packing and warehousing, something that the farm had not done before. This enables developing the product selection further.

At Gamma the BM innovation focuses primarily on using information technologies and communication channels in improving the internal processes and enhancing customer relations. The entrepreneur tells that customer interaction is the most important means to add value in their BM. Especially social media enables direct contact to the final customer even when products are sold through retail stores. Production is managed based on real-time 
information from sales and customer feedback. Product quality and operative efficiency of production are secured with digital customer information, measurements of production and harvesting "We get information about by whom, what and from which plot was harvested." Information is accumulated to support strategic decision making. As a result, the company, for example, started strawberry freezing service and diversified into accommodate services. Thus, Gamma's approach to BM innovation is also incremental changes, combining diversification (similar to Alpha) and specialization (similar to Beta).

Delta's value proposition contains better indoor air quality: "Our company offers a new product to a new market. No one has ever made such a product before. We have designed and built it by ourselves from the start." The company operations are linked to multiple traditional industries and the services are based on having a network: "We combine two different markets. One is the indoor air purification market and the other one is indoor landscaping market." Maintenance service is done with the remote controlling system, sensors and the artificial intelligence. They were familiar with business modelling methods and systematically designed a novel BM for their product. "We are selling that air as a service and our business model is to develop, sell and maintain those smart green walls or biological air purification."

The BM of Epsilon is also radical and new. Most radical aspect in the BM is that it is aiming at scalable concept that can be multiplied around the world: "You just need to find your own niché, something that you do better than anybody else in the world." Yet, developing the BM has been an iterative process: "I wrote many business plans and went abroad to see how this business is being conducted. Thereafter, I made quite many changes to plan still." Epsilon's water-based production is using processes and methods uncommon to the industry. The entrepreneur emphasizes that the purpose of business is to yield profit and the operations are modified constantly. "Of course, I want to sell hell of a lot more... It then in a way changes also the cost structure. Fixed costs and variable costs, so the game becomes completely different." The Epsilon entrepreneur emphasizes process efficiency also by searching new ways to organize the operations.

The Zeeta entrepreneur's radical BM innovation builds on the digitalization and automation. The efficiency of greenhouse production can be multiplied by growing plants in multiple layers and as the entrepreneur put it: "It can be located close to the customer or so that we can gain synergies." The operations are also well scalable and can be managed from a distance. Partnership with a multinational technology company has promoted financially the scalability of the operations. On the other hand, for the entrepreneur it is important to understand the consumer as a social actor. "Consumers feel that this is a safe product, here it is important that I'm able to eat this salad. Maybe even know who the gardeners are. I think the social aspect is very important." The growth and internationalization plan as well as the BM of Zeeta in terms of both the production process and organizing are all radical in the industry.

\section{Analysis and discussion}

The analysis shows that three firms have engaged in incremental BM innovation: non-extreme changes and no substantial discontinuity in the business. The changes are related either to diversifying - using the assets in a new way - and/or specializing in core farming production. In comparison, the other three businesses had more radical BM innovations. All three have analytical and systematic approach in developing their BMs. What really distinguishes them from the group of incremental innovation firms could be described as "thinking big". Their aim is to serve international markets. Thinking big entails also taking bigger risks. In addition, these entrepreneurs seem to have more versatility in their competencies, which might be related to their radical approach to BM innovation.

Interestingly, the entrepreneurs who do incremental innovations all run established family firms, and radical BM innovations are coming from non-family firms. This would support previous literature claiming that family businesses in agriculture would be more conservative when innovating their BM (e.g. Duran et al. 2016). However, although potentially representative of the wider phenomenon, this difference might also be partly due to the case selection of the study, thus pointing towards the need for more (quantitative) investigation of the causal and structural relationships. There are many potential contributors to this finding, such as the entrepreneurs' education, their attitude towards risks and the company form and financial situation. Overall, directing attention to the individual entrepreneurs' competencies behind BM innovation is important to raise awareness of the role of individual agency in industrial renewal. 
To evaluate the entrepreneurial competencies we formed competence profiles for the entrepreneurs (in Appendix 1). It reveals that all examined entrepreneurs were strong in at least in one of the six competency areas. Each family firm entrepreneur has one area where they have strong competency - two in formulating strategies and one in identification of market. On the other hand, the non-family firm entrepreneurs demonstrate more breadth in strong competencies. Particularly Delta and Zeeta entrepreneurs stand out in the analysis as they excel in five areas out of six. This finding provides support to the literature (Foss and Saebi, 2017) proposing that entrepreneurial competencies is an important driver for BM Innovation. It also suggests that larger breadth in the capabilities is needed when the aim is to make radical BM innovations.

Scrutinizing the entrepreneurial competencies in more detail reveals that specific dimensions of competency areas are recurring in the findings; We could identify core dimensions for each of the six competence areas (summarized in Table 2). Remembering that all the companies analyzed in this study were successful in their BM innovation, we suggest that these 12 dimensions could be used to measure the entrepreneurial competency in further $\mathrm{BM}$ Innovation studies. This is a relevant contribution especially for quantitative studies, where it is a necessity to be able to focus the survey on the core dimensions of the competences.

Table 2. Focal features of entrepreneurial BM innovation competencies

\begin{tabular}{|l|}
\hline Market identification \\
\# careful selection of markets and understanding customer needs \\
\# constant re-evaluation of markets \\
Product innovation \\
\# emphasis on production process and technology utilization \\
\# servitization (introducing new services and products as services using existing resources) \\
\# entrepreneur's vision as the driving force \\
\# continuing family legacy in family firms \\
Environmental scanning \\
\# the market side: customers and competition \\
Recognizing opportunities \\
\# ability to make use of the identified opportunities \\
\# building a BM to leverage an opportunity \\
\hline Formulating strategies \\
\# motivating and engaging partners \\
\# questioning and asking "stupid" questions
\end{tabular}

\section{Conclusions}

This article is among the first to study entrepreneurial competencies as an internal driver for companies to carry out BM innovation. The aim was to offer insights by studying the entrepreneurial competencies of successful entrepreneurs in the particular context of horticulture industry, and the type of BM innovations carried out by the entrepreneurs. The case studies represent successful firms that have been engaged in BM innovation.

Altogether, the empirical analysis demonstrates the significance of entrepreneurial competencies for BM innovation. This study clearly shows the link between entrepreneurial competencies and the BM innovation, and thus provides support to the literature (Foss and Saebi 2017) proposing that entrepreneurial competencies is an important internal driver for BM Innovation.

In all studied successful BM cases the entrepreneur had a strong competence in at least one of the six areas identified by Mitchelmore and Rowley (2010). Our findings also suggest that a larger breadth in the capabilities is needed when the company aims to make radical BM innovations. 
Moreover, we identify two dimensions in each of the entrepreneurial competence areas (Mitchelmore and Rowley 2010), which appear to be important antecedents for BM Innovation. Our suggestions is that these 12 dimensions could be utilized in further BM Innovation studies for measuring the entrepreneurial competency level.

This study also has clear implications on renewing the education and training practices of the horticulture industry. In the education it should be explicitly taken into account that the farmers are entrepreneurs and they should be able to analyze and make deliberate changes to their BM when needed. This requires sufficient or preferably strong capabilities in the six entrepreneurial competencies: identification of markets, product innovation, idea generation, environmental scanning, recognizing opportunities and formulating strategies.

Further studies on the relationship between entrepreneurial competencies and the BM innovation is needed to deepen the understanding about the BM innovation in everyday practices, especially in the context of SMEs. Particularly in industries, where the great majority of firms are very small, the competencies of individual entrepreneurs' play a significant role for industry renewal.

This study has taken the first step towards this direction by building an entrepreneurial BM innovation competency framework to analyze the motivations and competencies of successful entrepreneurs in horticulture industry. As a practical implication for horticulture industry and its renewal, the significance of entrepreneurial competencies on BM innovation can be highlighted based on this study. To ensure industry viability and enhance renewal in the face of changing conditions, it is important to pay attention to developing entrepreneurial competencies, e.g. through education. In addition, more research is needed how entrepreneurs (or aspiring entrepreneurs) can acquire and develop the competencies discussed above.

\section{References}

Alsos, A.G., Ljunggren, E. \& Toril Pettersen, L. 2003. Farm-based entrepreneurs: what triggers the start-up of new business activities? Journal of Small Business and Enterprise Development 10: 435-443. https://doi.org/10.1108/14626000310504747

Baum, J.R. 1994. The relationship of traits, competencies, motivation, strategy and structure to venture growth. PhD dissertation, University of Maryland, College Park, MD.

Berends, H., Smits, A., Reymen, I. \& Podoynitsyna, K. 2016. Learning while (re) configuring: Business model innovation processes in established firms. Strategic Organization 14: 181-219. https://doi.org/10.1177/1476127016632758

Bird, B. 1988. Implementing Entrepreneurial Ideas: The Case for Intention. Academy of Management Review 13: 442-453. https://doi.org/10.5465/amr.1988.4306970

Bird, B. 1995. Toward a theory of entrepreneurial competence. Advances in Entrepreneurship, Firm Emergence and Growth 2: 51-72. Bonakdar, A. 2015. Business Model Innovation. PhD dissertation. University of St. Gallen. 112 p.

Bucherer, E., Eisert, U. \& Gassmann, O. 2012. Towards Systematic Business Model Innovation: Lessons from Product Innovation Management. Creativity and Innovation Management 21: 183-198. https://doi.org/10.1111/j.1467-8691.2012.00637.x

Chandler, G.N. \& Jansen, E. 1992. The founder's self-assessed competence and venture performance. Journal of Business Venturing 7: 223-236. https://doi.org/10.1016/0883-9026(92)90028-P

Cortimiglia, M.N., Ghezzi, A. \& Frank, A.G. 2016. Business model innovation and strategy making nexus: evidence from a crossindustry mixed-methods study. R\&D Management 46: 414-432. https://doi.org/10.1111/radm.12113

DaSilva, C.M. \& Turkman, P. 2014. Business Model: What It Is and What It Is Not. Long Range Planning 47: 379-389.https://doi. org/10.1016/j.Irp.2013.08.004

Demil, B. \& Lecocq, X. 2010. Business model evolution: in search of dynamic consistency. Long range planning 43: 227-246. https://doi.org/10.1016/j.lrp.2010.02.004

Duran, P., Kammerlander, N., Van Essen, M. \& Zellweger, T. 2016. Doing more with less: Innovation input and output in family firms. Academy of Management Journal 59: 1224-1264. https://doi.org/10.5465/amj.2014.0424

Dubois, A. \& Gadde, L. 2002. Systematic Combining: An Abductive Approach to Case Research. Journal of Business Research 55 : 553-560. https://doi.org/10.1016/S0148-2963(00)00195-8

EASME 2015. Horizon 2020's SME Instrument. http://ec.europa.eu/easme/en/horizons-2020-sme-instrument. Accessed 2 January 2019.

English Oxford Dictionary. https://en.oxforddictionaries.com/definition/entrepreneur

Fleetwood, S. 2005. Ontology in organization and management studies: A critical realist perspective. Organization 12: 197-222. https://doi.org/10.1177/1350508405051188

Fisher, R.J. 1993. Social Desirability Bias and the Validity of Indirect Questioning. Journal of Consumer Research 20: 303-315. https://doi.org/10.1086/209351

Foss, N.J. \& Saebi, T. 2017. Fifteen Years of Research on Business Model Innovation: How Far Have We Come, and Where Should We Go? Journal of Management 43: 200-227. https://doi.org/10.1177/0149206316675927 
Freiling, J. 2004. A Competence-based Theory of the Firm. Management revue. The International Review of Management Studies 15: 27-52. https://doi.org/10.5771/0935-9915-2004-1-27

Gioia, D.A., Corley, K.G. \& Hamilton, A.L. 2013. Seeking Qualitative Rigor in Inductive Research. Organizational Research Methods 16: 15-31. https://doi.org/10.1177/1094428112452151

Gümüsay, A.A. \& Bohné, T.M. 2018. Individual and organizational inhibitors to the development of entrepreneurial competencies in universities. Research Policy 47: 363-378. https://doi.org/10.1016/j.respol.2017.11.008

Hartmann, M., Oriani, R. \& Bateman, H. 2013. The Performance Effect of Business Model Innovation: An Empirical Analysis of Pension Funds. In 35th DRUID Celebration Conference, 17-19. https://doi.org/10.5465/ambpp.2013.10986abstract

Heikkilä, J. \& Heikkilä, M. 2017. New Business Development, BMI and Effectuation. In: Pucihar, A., Kljajić Borštnar, M., Kittl, C., Ravesteijn, P., Clarke, R. \& Bons, R. (eds.). Digital Transformation - From Connecting things to Transforming our Lives, Proceedings of 30th Bled eConference. p. 197-204.

Heikkilä, M., Bouwman, H. \& Heikkilä, J. 2018. From Strategic goals to BMI paths. Journal of Small Business and Enterprise Development 25: 107-128. https://doi.org/10.1108/JSBED-03-2017-0097

Huijben, J.C. \& Verbong, G.P. 2013. Breakthrough without subsidies? PV business model experiments in the Netherlands. Energy Policy 56: 362-370. https://doi.org/10.1016/j.enpol.2012.12.073

Karlsson, N., Halila, F., Mattsson, M. \& Hoveskog, M. 2017. Success factors for agricultural biogas production in Sweden: A case study of business model innovation. Journal of Cleaner Production 142: 2925-2934. https://doi.org/10.1016/j.jclepro.2016.10.178

Koryak, O., Mole, K.F., Lockett, A., Hayton, J.C., Ucbasaran, D. \& Hodgkinson, G.P. 2015. Entrepreneurial leadership, capabilities and firm growth. International Small Business Journal 33: 89-105. https://doi.org/10.1177/0266242614558315

Kyndt, E. \& Baert, H. 2015. Entrepreneurial competencies: Assessment and predictive value for entrepreneurship. Journal of Vocational Behavior 90: 13-25. https://doi.org/10.1016/j.jvb.2015.07.002

Lampela, H., Taipale-Erävala, K. \& Heilmann, P. 2017. SME Business Models and Competence Changes. International Journal of Management, Knowledge and Learning 6: 175-192.

Lans, T., Biemans, H., Mulder, M. \& Verstegen, J. 2010. Self-awareness of mastery and improvability of entrepreneurial competence in small businesses in the agrifood sector. Human Resource Development Quarterly 21: 147-168. https://doi.org/10.1002/ hrdq.20041

Lindgardt, Z., Reeves, M., Stalk, G. \& Deimler, M.S. 2009. Business Model Innovation: When the Game Gets Tough, Change the Game. The Boston Consulting Group, Boston, MA. 8 p.

Loué, C. \& Baronet, J. 2012. Toward a new entrepreneurial skills and competencies framework: A qualitative and quantitative study. International Journal of Entrepreneurship and Small Business 17: 455-477. https://doi.org/10.1504/IJESB.2012.050164

Mäkinen, H. 2013. Farmers' managerial thinking and management process effectiveness as factors of financial success on Finnish dairy farms. Agricultural and Food Science 22: 452-465. https://doi.org/10.23986/afsci.8147

Man, T.W.Y, Lau, T. \& Chan, K.F. 2002. The competitiveness of small and medium enterprises. A conceptualization with focus on entrepreneurial competencies. Journal of Business Venturing 17: 123-142. https://doi.org/10.1016/S0883-9026(00)00058-6

Man, T.W.Y., Lau, T. \& Snape, E. 2008. Entrepreneurial Competencies and the Performance of Small and Medium Enterprises: An Investigation through a Framework of Competitiveness. Journal of Small Business and Entrepreneurship 21: 257-276. https:// doi.org/10.1080/08276331.2008.10593424

Mattila, T., Manninen, M., Rikkonen, P. \& Kymäläinen, H.-R. 2008. Management of investment processes on Finnish farms. Agricultural and Food Science 17: 18-30. https://doi.org/10.2137/145960608784182263

Meroño-Cerdán, A.L., López-Nicolás, C. \& Molina-Castillo, F.J. 2018. Risk aversion, innovation and performance in family firms. Economics of Innovation and New Technology 27: 189-203. https://doi.org/10.1080/10438599.2017.1325569

Mitchelmore, S. \& Rowley, J. 2010. Entrepreneurial competencies: a literature review and development agenda. International Journal of Entrepreneurial Behavior \& Research 16: 92-111. https://doi.org/10.1108/13552551011026995

Mitchelmore, S. \& Rowley, J. 2013. Entrepreneurial competencies of women entrepreneurs pursuing business growth. Journal of Small Business and Enterprise Development 20: 125-142. https://doi.org/10.1108/14626001311298448

Mulder, M., Lans, T., Verstegen, J., Biemans, H. \& Meijer, Y. 2007. Competence development of entrepreneurs in innovative horticulture. Journal of Workplace Learning 19: 32-44. https://doi.org/10.1108/13665620710719330

Patton, M.Q. 2002. Qualitative research and evaluation methods (3rd ed.). Thousand Oaks, CA: Sage. 598 p.

Penrose, E. 1959. The theory of the growth of the firm. Oxford University Press, Oxford. $296 \mathrm{p}$.

Pohle, G. \& Chapman, M. 2006. IBM's global CEO report 2006: business model innovation matters. Strategy and Leadership 34: 34-40. https://doi.org/10.1108/10878570610701531

Pukkinen, T. 2018. The role of entrepreneurial orientation and dynamic capabilities in firm performance. Doctoral dissertation, Annales Universitatis Turkuensis E 26. 235 p.

Rikkonen, P. \& Aakkula, J. 2012. Maataloustuotannon muuttuva toimintaympäristö. In: Latukka, A., Nurro, M. \& Ahlstedt, J. (eds.) Moderni 100-vuotias suuntaa tulevaisuuteen: Maatalouden kannattavuuskirjanpidon juhlajulkaisu. MTTL:n julkaisuja: 113. 64 p. (in Finnish)

Santandreu-Mascarell, C., Garzon, D. \& Knorr, H. 2013. Entrepreneurial and innovative competences, are they the same? Management Decision 51: 1084-1095. https://doi.org/10.1108/MD-11-2012-0792

Sánchez, J. 2011. University training for entrepreneurial competencies: Its impact on intention of venture creation. International Entrepreneurship and Management Journal 7: 239-254. https://doi.org/10.1007/s11365-010-0156-x 
Schneider, S. \& Spieth, P. 2013. Business model innovation: towards an integrated future research agenda. International Journal of Innovation Management 17: 1-34. https://doi.org/10.1142/S136391961340001X

Sivertsson, O. \& Tell, J. 2015. Barriers to business model innovation in Swedish agriculture. Sustainability 7: 1957-1969. https:// doi.org/10.3390/su7021957

Stenholm, P. \& Renko, M. 2016. Passionate bricoleurs and new venture survival. Journal of Business Venturing 31: 595-611. https://doi.org/10.1016/j.jbusvent.2016.05.004

Stevenson, H.H. \& Jarillo, J.C. 1991. A new entrepreneurial paradigm and nbsp. In: Etzioni, A. \& Lawrence, P.R. (eds.). Socio-economics: Toward a New Synthesis. New York: Armank. p. 185-208.

Ucbasaran, D., Westhead, P. \& Wright, M. 2001. The focus of entrepreneurial research: contextual and process issues. Entrepreneurship theory and practice 25: 57-80. https://doi.org/10.1177/104225870102500405

Vik, J. \& McElwee, G. 2011. Diversification and the entrepreneurial motivations of farmers in Norway. Journal of small business management 49: 390-410. https://doi.org/10.1111/j.1540-627X.2011.00327.x

Wagener, S., Gorgievski, M. \& Rijsdijk, S. 2010. Businessman or host? Individual differences between entrepreneurs and small business owners in the hospitality industry. The Service Industries Journal 30: 1513-1527. https://doi.org/10.1080/02642060802624324

Wirtz, B.W., Pistoia, A., Ullrich, S. \& Göttel, V. 2016. Business Models: Origin, Development and Future Research Perspectives. Long Range Planning 49: 36-54. https://doi.org/10.1016/j.Irp.2015.04.001

Zott C., Amit R. \& Massa, L. 2011. The Business Model: Recent Developments and Future Research. Journal of Management 37:1019-1042. https://doi.org/10.1177/0149206311406265 